\title{
Seeding Time Affects Bermudagrass Establishment in the Transition Zone Environment
}

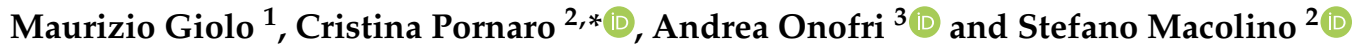 \\ 1 Council for Agricultural Research and Economics, Research Centre for Plant Protection and Certification, \\ 36045 Lonigo (VI), Italy; maurizio.giolo@crea.gov.it \\ 2 Department of Agronomy, Food, Natural resources, Animals and the Environment, University of Padova, \\ 35020 Legnaro (PD), Italy; stefano.macolino@unipd.it \\ 3 Department of Agricultural, Food and Environmental Sciences, University of Perugia, 06121 Perugia, Italy; \\ andrea.onofri@unipg.it \\ * Correspondence: cristina.pornaro@unipd.it
}

Received: 23 July 2020; Accepted: 4 August 2020; Published: 6 August 2020

\begin{abstract}
Bermudagrass is becoming increasingly popular in the Mediterranean transition zone of Europe for establishing new sports and recreational turfgrasses. In these regions, the quality and winter hardiness of bermudagrass turf is influenced by the establishment. It has been demonstrated that an early establishment of bermudagrass results in a longer growing season with a greater stolon and rhizome production, which favors cold hardiness and a quicker green up after the first winter. Dormant seeding is reported to be beneficial for an early establishment. However, the response to early seeding depends on local environmental conditions. A field study was conducted in northeastern Italy during spring 2018 and 2019. Four bermudagrass cultivars ('Transcontinental', 'Jackpot', 'SR9554', and 'La Paloma') were compared under three seeding times from March to May to evaluate whether early spring seeding allows anticipating the establishment of bermudagrass compared with late spring seeding which generally benefits of better temperatures for germination and growth. The number of days from seeding to the emergence and from seeding to the full establishment were determined, and the number of seedlings was counted in each plot. Late March seeding assured the earliest establishment. This result could be due to the quick lateral spreading of seedlings as the emergence occurred about 15 days later in the late March seeding compared with April and May seedings. Results also displayed that the speed of establishment was positively related to the number of emerged seedlings. 'Transcontinental', 'Jackpot', and 'SR9554' performed similarly, whereas 'Jackpot' showed a slower establishment.
\end{abstract}

Keywords: number of seedlings; green turf cover; degree days; emergence

\section{Introduction}

The Mediterranean region of Europe is placed between the temperate and rainy climate of Central Europe and the arid area of North Africa, and its climate is characterized by mild and wet winters and hot and dry summers [1]. Italy, placed in the heart of the Mediterranean Sea, is a typical transition zone [2]. In this area, warm-season turf species are suitable but not always appreciated due to the long dormancy period of up to 6 months [3-5]. In winter, warm-season species turn yellow and survive using reserves accumulated during the previous growing season in stolons and rhizomes [6-8]. Therefore, the performance of warm-season species in transition zones is mainly related to the duration of the dormancy period [4]. Although winter dormancy can limit widespread distribution of these species in Europe, warm-season species are preferred over cool-season ones [9] due to their lower water demand, higher wear tolerance and rapid recovery from injuries by means of vigorous stolons and rhizomes [10,11]. 
Among warm-season turf species, bermudagrass (Cynodon spp.) is the most widely used $[8,10,12]$ with a large number of cultivars available. In the turfgrass industry, there are both seeded and vegetative cultivars, with the latter considered highly performing due to a greater stolon and rhizome development [11]. However, seeded-type bermudagrass cultivars are the most used in the upper transition-zone environments of Europe and are reported to grow successfully without facing significant cold damage during the winter months [8]. In transition zones, cultivar selection and management practices, including seeding time, should be carefully evaluated $[13,14]$ as, despite their good cold tolerance, some seeded cultivars can still suffer from severe temperatures in winter, resulting in delayed spring green-up [4]. In these areas, bermudagrass is generally seeded from late spring to early summer, when soil temperatures are favorable for germination and growth. The effects of soil temperature on the establishment of warm-season species have been widely documented [15,16]. It has been also demonstrated that the date of establishment has substantial effects on long-term turfgrass quality. Richardson et al. [17] reported that planting bermudagrass in April and May in Arkansas results in improving recovery from winter and in stolons development than planting it in June. Moreover, they found significant differences among cultivars tested ('Yukon', 'Princess', 'Jackpot', 'Mirage', 'NuMex Sahara', and 'Mohawk') with 'Yukon' showing an earlier spring green-up. Pornaro et al. [18] in a field study carried out in northeastern Italy, investigated the effect of winter (January and February) and spring (April) seeding on the establishment of 'Sea Spray' seashore paspalum (Paspalum vaginatum Swartz) in comparison to 'Riviera' and 'Sovereign' bermudagrass. All of them had a faster establishment when seeded in spring than in winter, but the establishment occurred earlier in the season for the winter seeding. Similar findings were obtained by Shaver et al. [12], who demonstrated the faster establishment of early spring seeding compared with late spring seeding of 'Riviera' and 'Princess 77'.

Seeded bermudagrass cultivars are considered easy to establish due to relatively rapid germination and seedlings growth [19]. However, the response of cultivars to seeding time in terms of germination and establishment is strongly related to local environmental conditions and cultivar adaptation $[17,18]$. Therefore, studies at the regional scale are needed to help turf specialists in choosing the optimum seeding time. A field trial was conducted in northeastern Italy during spring 2018 and 2019, comparing four bermudagrass cultivars available on the Italian turf market. The study aimed to evaluate whether early spring seeding allows anticipating the establishment of bermudagrass compared with late spring seeding, which is the recommended seeding time for this area.

\section{Materials and Methods}

A field study was conducted from late March to early July 2018 and 2019 at the experimental agricultural farm of Padova University in Legnaro, northeastern Italy $\left(45^{\circ} 20^{\prime}, 11^{\circ} 57^{\prime} \mathrm{E}\right.$, elevation $8 \mathrm{~m}$ ). The area is characterized by a humid subtropical climate with the annual minimum, average, and maximum temperature, respectively, of $8.9,13.6$, and $18.7^{\circ} \mathrm{C}$, and rainfall of $842 \mathrm{~mm}_{\text {year }}{ }^{-1}$ (1994-2019 series) [20]. The soil at the site consisted of a clay loam [21]: $28.0 \%$ silt, $27.7 \%$ clay, and $44.3 \%$ sand with $\mathrm{pH}$ of $8.17,2.77 \%$ organic matter (Walkley-Black method), $0.14 \mathrm{mg} \mathrm{kg}^{-1} \mathrm{~N}$ content, $3.9 \mathrm{mg} \mathrm{kg}^{-1}$ of available phosphorus (Olsen method), and $170.8 \mathrm{mg} \mathrm{kg}^{-1}$ exchangeable potassium (buffered $\mathrm{BaCl}_{2}$ method). The establishment response of four bermudagrass cultivars: 'Transcontinental', 'Jackpot', 'SR9554', and 'La Paloma' under three seeding dates with about 30 day-interval [27 March (S1), 26 April (S2), and 27 May (S3) in 2018 and 22 March (S1), 3 May (S2), and 4 June (S3) in 2019] was evaluated. The experimental design was a split-plot with seeding times as main plot and cultivars as subplot $(1.50 \times 1.50 \mathrm{~m})$ with three replications. Plots were hand-seeded at a rate of $2.5 \mathrm{~g} \mathrm{~m}^{2}$ pure live seed [18]; seeding rates for coated cultivars (SR9554, Transcontinental) were increased to match seed number per plot of uncoated seed $\left(3.906 \mathrm{~g} \mathrm{~m}^{-2}\right)$. Cultivars were selected among those recently introduced to the Italian turf market, and certified seed was used. Sprinkler irrigation consisted of $5 \mathrm{~mm}$ daily from seeding until emergence and $10 \mathrm{~mm}$ every other day from emergence until full establishment. Irrigation was applied regardless of the natural rainfall. A complex granular fertilizer (8-24-24, NPK) was incorporated into the soil at a rate of $50 \mathrm{~kg} \mathrm{ha}^{-1}$ of $\mathrm{N}$ before seeding. Additional $60 \mathrm{~kg} \mathrm{ha}^{-1}$ of $\mathrm{N}$ 
was applied, as urea (46-0-0, NPK), 10 days after emergence. Both broad and narrow-leaf weeds were hand-removed at a weekly interval.

Three temperature sensors (thermocouples) connected to a data logger (Spectrum Technologies, Inc., Plainfield, IL, USA) were installed at the soil depth of $2.5 \mathrm{~cm}$. Soil temperature was recorded hourly, and the average daily temperature was calculated (Figure 1).

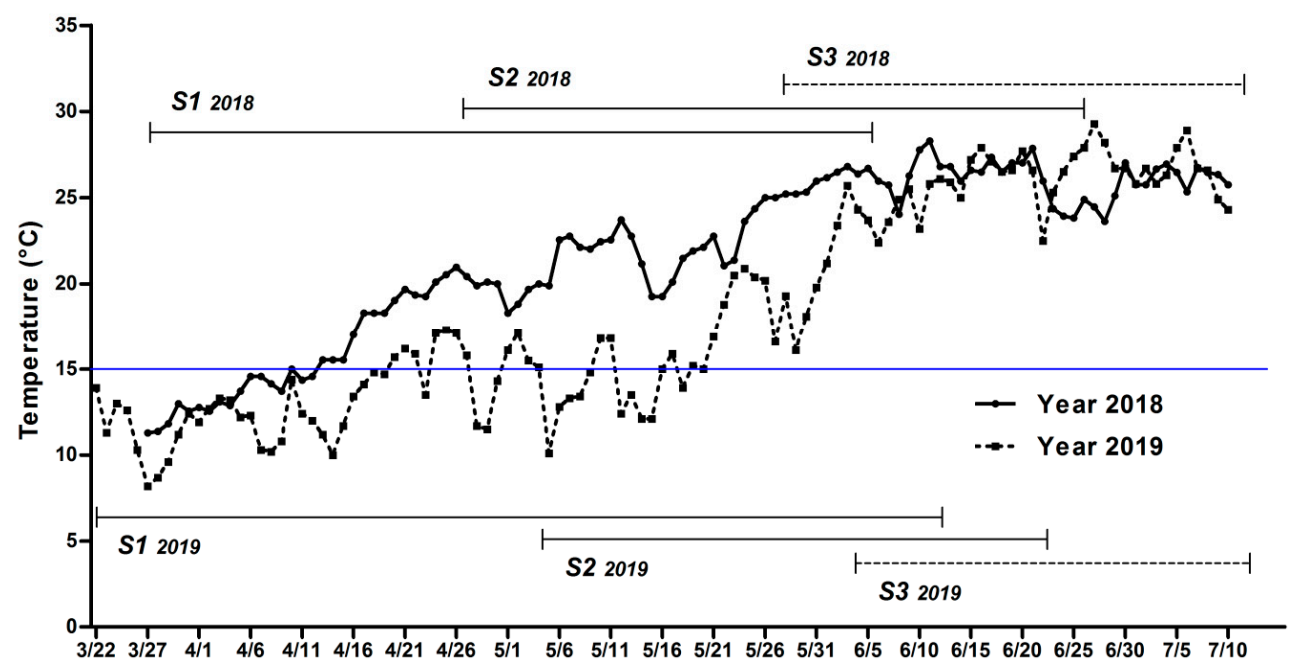

Figure 1. Average daily soil temperatures $(2.5 \mathrm{~cm}$ depth) during the establishment period of three seeding times (S1, S2, and S3) in 2018 and 2019. The blue line corresponds to the base temperature for bermudagrass $\left(15^{\circ} \mathrm{C}\right)$.

Meteorological data were collected at a nearby station located in the experimental farm. In 2018, the rainfalls of April, May, and June was 30, 70, and $90 \mathrm{~mm}$, respectively, whereas in 2019, it was 131, 201, and $9 \mathrm{~mm}$, respectively. The average daily air temperature at $2 \mathrm{~m}$ above ground did not differ substantially from the soil temperature recorded at $2.5 \mathrm{~cm}$ depth (Figure 2).

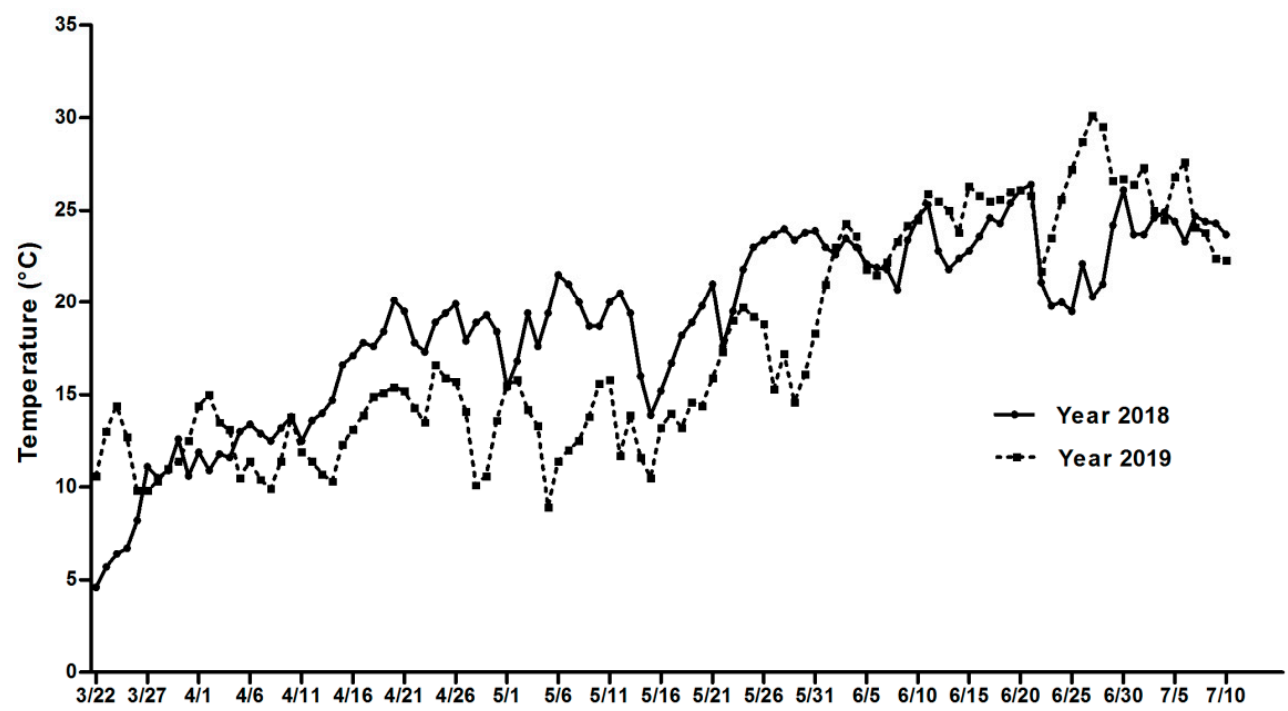

Figure 2. Average daily air temperatures at $2 \mathrm{~m}$ above the ground during spring 2018 and 2019 in Legnaro (Padova), northeastern Italy.

At the emergence, the number of seedlings per unit area was determined by counting the seedlings in a metal frame $(10 \mathrm{~cm} \times 10 \mathrm{~cm})$ placed randomly on the plot surface. Three measurements per plot were taken. The number of days from seeding to the emergence (DFSseed) was determined for each plot. From the emergence until the end of July of both years, green turfgrass cover was weekly 
determined using digital image analysis technique [22]. The sigmoidal model [23,24] was the best to describe the dynamic of establishment (GraphPad Prism 5.1 for Windows; GraphPad Software, La Jolla, CA). According to Leinauer et al. [25], the establishment was considered satisfactory when $75 \%$ of turfgrass cover was reached. This model was used to calculate the number of days from seeding (DFS) and the degree days from seeding (DD) to reach $75 \%$ green cover. The DD were calculated using daily average soil temperature at $2.5 \mathrm{~cm}$ depth and $15^{\circ} \mathrm{C}$ as the base temperature [26,27].

The following parameters were subjected to the analysis of variance: (i) days from seeding to the emergence (DFSseed), (ii) number of seedlings at the emergence, (iii) days from the first seeding time to reach $75 \%$ green cover (DFS1), (iv) days from seeding to reach $75 \%$ green cover (DFS), and (v) degree days to reach $75 \%$ green cover (DD). In both years of investigation, plots seeded in the third seeding time did not reach 75\% green cover before the end of July, which was very late compared with S1 and S2. Therefore, DFS1, DFS, and DD for S3 were not included in the statistical analysis.

The analysis of variance was performed using the R statistical environment [28] together with the package 'emmeans' [29]. Data were used to parametrize a Linear Mixed Model, where the 'Year', 'Seeding Time', 'Cultivar', and all the interactions therein were included as fixed effects, whereas the blocks within years and the main plots within blocks were included as random effects, to account for the clustering of observations and ensure the independence of model residuals. Normality and homoscedasticity of residuals were checked by using graphical analyses. The means for the significant interaction of the highest order were compared by using a multiple comparison testing procedure, accounting for multiplicity [30]. Correlation between number of seedlings emerged and DFS was also performed to investigate the influence of plant density on establishment. Pearson correlation coefficient was calculated with XLSTAT [31].

\section{Results}

The development of turfgrass green cover for S1 and S2 of the 2 years of experimentation (2018 and 2019) is reported in Figure 3a,b. In both years, S1 allows reaching the reference cover (75\%) earlier than S2, even temperatures occurred following S2 treatment were higher than those following S1 (Figure 1).
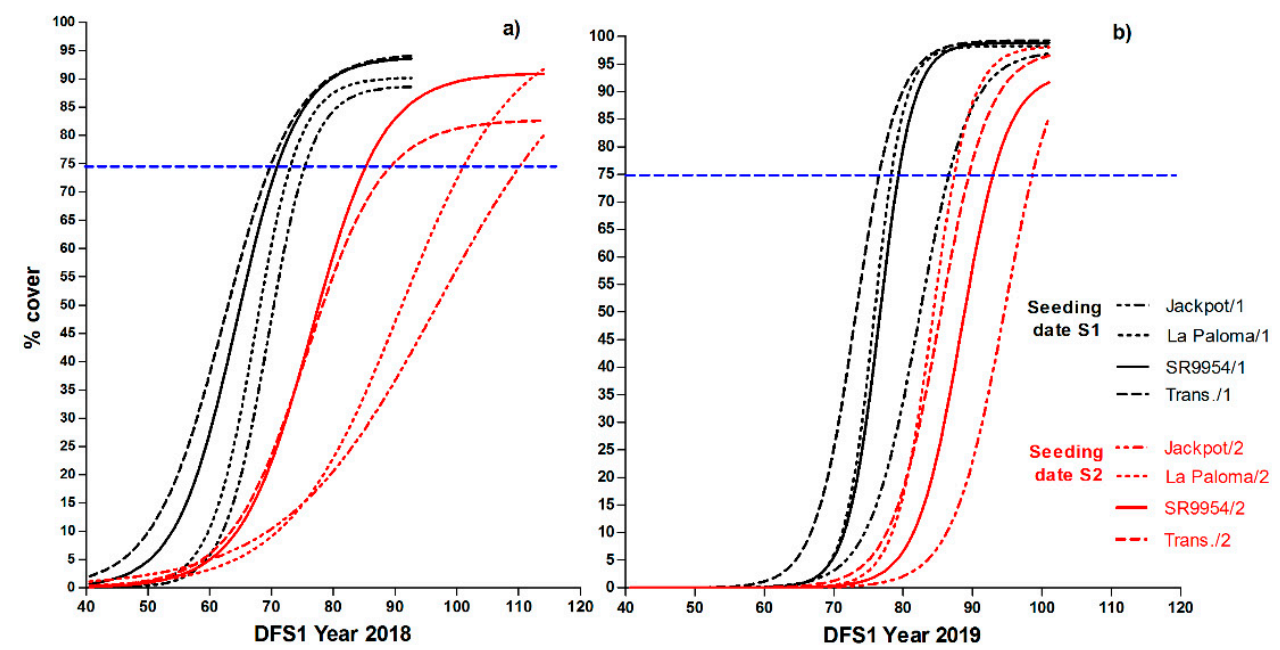

Figure 3. Turfgrass green cover of four bermudagrass cultivars in 2018 (a) and 2019 (b) as a function of the days from the first seeding time (DFS1). Graphs show the coverage predictions of sigmoidal models of both the first seeding time (S1) in black and the second seeding time (S2) in red. The blue dashed line shows the full establishment at $75 \%$ green cover.

The interaction between year and seeding time was significant for number of seedlings at the emergence and for DFS. The main effect of cultivar was significant for DFS1 and DD. Furthermore, seeding time significantly affected DFSseed and DFS1, whereas year affected DFSseed and DD (Table 1). 
Table 1. Analysis of variance testing the effects of year, seeding time, cultivar, and their interactions on days from seeding to the emergence (DFSseed), number of seedlings at the emergence (Seedlings $\mathrm{Nr}$ ), days from the first seeding time (DFS1), days from seeding (DFS), and degree days (DD) to reach $75 \%$ green cover.

\begin{tabular}{lccccc}
\hline \multicolumn{1}{c}{ Factors } & DFSseed & Seedlings Nr & DFS1 & DFS & DD \\
\hline Year & $<0.001$ & 0.019 & NS & NS & 0.037 \\
Seeding time & $<0.001$ & NS & 0.009 & 0.005 & NS \\
Cultivar & NS & $<0.001$ & $<0.001$ & $<0.001$ & $<0.001$ \\
Year $\times$ seeding time & NS & 0.009 & NS & 0.030 & NS \\
Year $\times$ cultivar & NS & NS & NS & NS & NS \\
Seeding time $\times$ cultivar & NS & NS & NS & NS & NS \\
Year $\times$ seeding time $\times$ cultivar & NS & NS & NS & NS & NS \\
\hline
\end{tabular}

NS = not significant at the 0.05 level of probability.

On average of both years of experimentation and the four cultivars tested, plots seeded at the first seeding time needed about 15 days more than plots seeded at the second and third seeding time to reach the emergence with, respectively, 43, 29, and 27 days. Likewise, DFSseed were higher in 2019 (37 days) than in 2018 (29 days). This difference in DFSseed seems related to differences in temperatures between the 2 years (Figure 1). In 2019, soil temperatures were lower than the germination base temperature for this species [26] until the end of May, and this may have negatively affected the germination for both S1 and S2. Regarding the number of seedlings at the emergence, higher values were observed for 'Transcontinental' than for 'Jackpot' and 'SR9554' (Figure 4a). The interaction between seeding time and year displayed differences only between S2 in 2018 and S3 in 2019, without differences within 2018 or 2019 (Figure 4b).

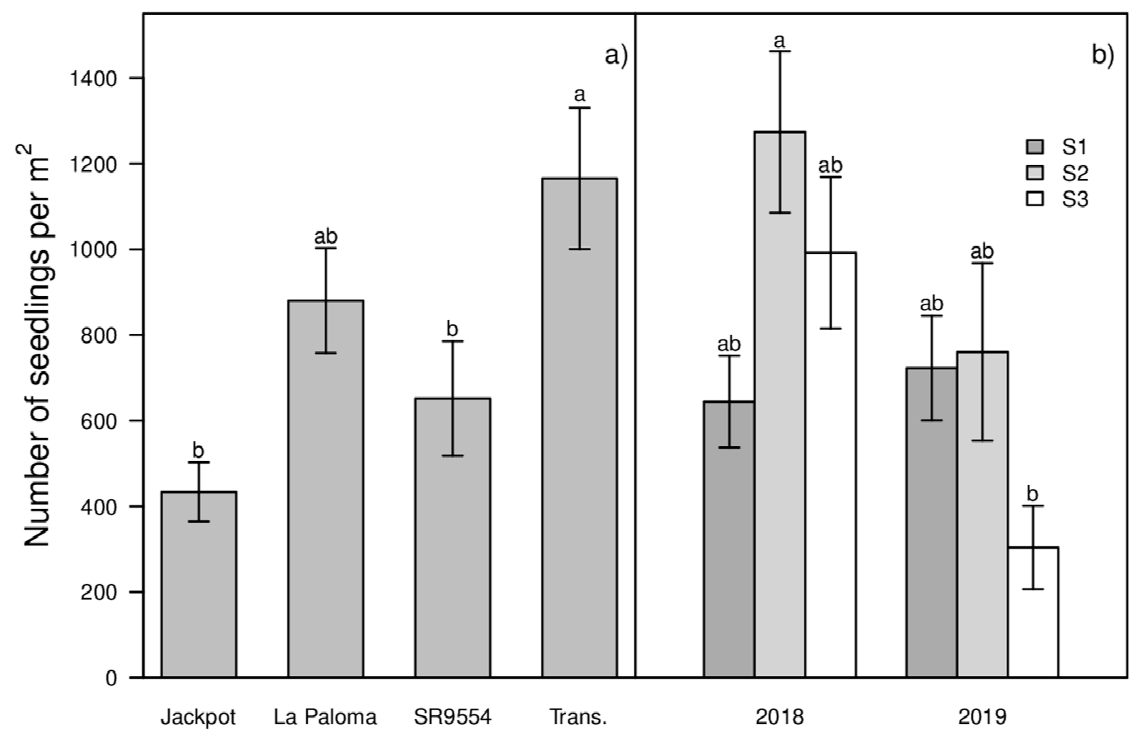

Figure 4. Number of seedlings as affected by the main effect of the cultivar (a) and the interaction between year and seeding time (b). Trans. = Transcontinental. Values with the same letter are not significantly different (Fisher's protected LSD test at the 0.05 probability level). Vertical bars represent standard errors.

Plots seeded at the second seeding time had higher DFS1 than plots seeded at the first seeding time (93 vs. 77). Days from the first seeding time to reach $75 \%$ green cover were higher for 'Jackpot' (92) than for 'La Paloma', 'SR9554', and 'Transcontinental' with, respectively, 86, 82, and 80 days. Jackpot was also the cultivar with higher DFS (Figure 5a). In 2018, DFS were not different for S1 and S2, 
whereas in 2019, S1 displayed higher DFS than S2. These could be the consequence of low temperatures in May 2019 that delayed seed germination of S1 (Figures 1 and 3).

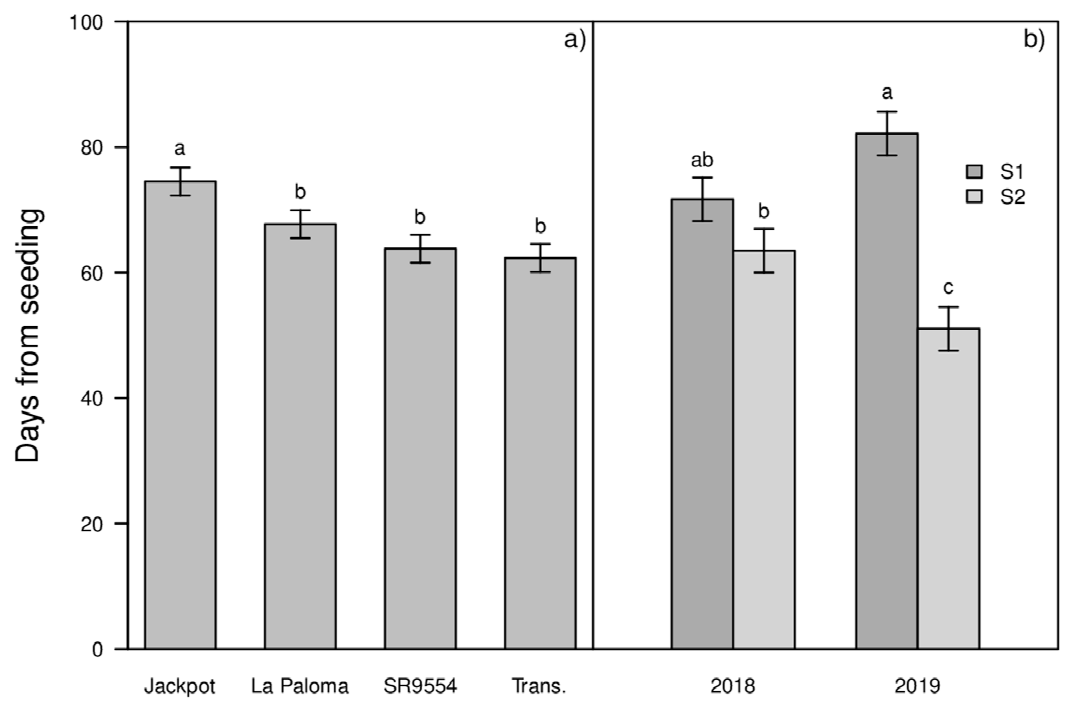

Figure 5. Days from seeding to reach $75 \%$ of green cover (DFS) as affected by the main effect of cultivars (a) and by the interaction between year and seeding time (b). Trans. = Transcontinental. Values with the same letter are not significantly different (Fisher's protected LSD test at the 0.05 probability level). Vertical bars represent standard errors.

The analysis of variance did not display any significant difference in DD between seeding times, whereas DD in 2018 were significantly higher than DD in 2019 (Figure 6a). Multiple comparisons among cultivars showed that DD of 'Jackpot' were significantly higher than DD of 'SR9554' and 'Transcontinental' (Figure 6b).

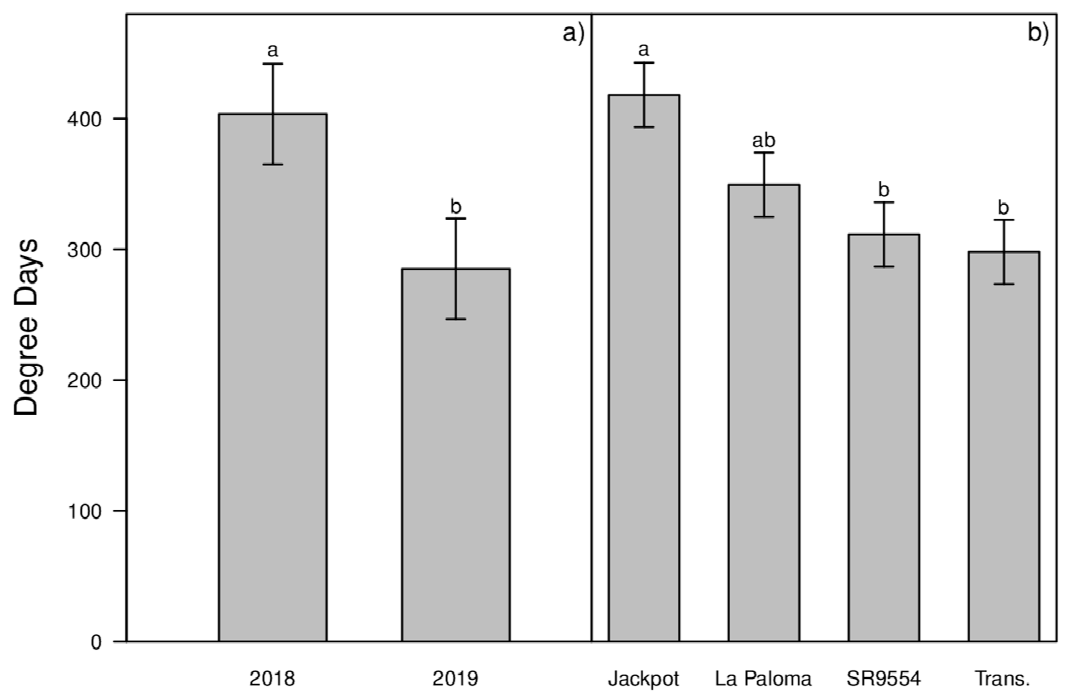

Figure 6. Degree days to reach $75 \%$ of green cover (DD) as affected by the main effect of year (a) and cultivar (b). Trans. = Transcontinental. Values with the same letter are not significantly different (Fisher's protected LSD test at the 0.05 probability level). Vertical bars represent standard errors.

\section{Discussion}

Differences between 2018 and 2019 in days needed to reach the emergence stage (DFSseed) were influenced by differences in temperatures between the 2 years of investigation (Figures 1 and 2). In 2019, the average daily soil temperature until mid-May rarely exceeded $15^{\circ} \mathrm{C}$, which is the base temperature 
for bermudagrass germination [26] (Figure 1). The first seeding time showed higher DFSseed than the others two seeding times as at the end of March, since average soil temperatures were not favorable for germination in both years (Figure 1). These results are consistent with previous findings obtained in laboratory reporting the estimated period for the beginning of bermudagrass germination in the field from early April to mid-May in northern Italy [32].

The second seeding time reached the coverage reference quicker than S1 in 2019 (Figure 5b) mainly due to favorable temperatures. Specifically, in 2019, soil temperatures were mostly nonoptimal until the end of May, and they were lower than the corresponding temperatures of 2018 until mid-June. At any rate, in both years of investigation, plots seeded at S2 were not able to reach $75 \%$ of green cover earlier than plots seeded at S1 regardless of the average temperatures. These results agreed with those found by Pornaro et al. [18] in a study comparing late winter seedings with a spring seeding. The establishment of S3 did not happen before mid-July in both years of the study, although soil temperatures as well as air temperatures were adequate for germination and growth. The main limitation for a late spring seeding is related to a short growing period available before bermudagrass stops growing in the fall that in the North Italy correspond to the middle of October.

Our results also displayed different behavior among the cultivars tested, but we did not find the interaction between cultivars and seeding time. At emergence, we found a higher number of seedlings for 'Transcontinental' than for 'Jackpot' and 'SR9554'. However, 'Jackpot' was the worst-performing cultivar in the study area as it showed significant higher DFS1, DFS, and DD than the other cultivars. 'La Paloma' performed similarly to 'Jackpot' most probably because of the similarity in thermal time requirement for germination [32]. Likewise, Richardson et al. [19] in Arkansas found a slow establishment of 'Jackpot'. As expected, we found that the number of seedlings at emergence was negatively correlated with DFS $(r=-0.31 ; p=0.03)$. However, despite this relationship, cultivars with lower number of seedlings at the emergence (Figure 4a) were not necessarily the slower to establish (Figure 5a). Both seedlings density and stolonization contributed in different ways and times to the establishment $[11,33]$. The speed of stolonization is, in turn, influenced by growing conditions in the period following the emergence. These results suggested that a quick establishment can be reached even with few seedlings. The speed of establishment seemed to be highly affected by cultivars and their response to temperatures occurring after the emergence.

\section{Conclusions}

The present study revealed that in northeastern Italy, establishment wise, the seeding of bermudagrass in March is more favorable than in late May/early June. The former provides a longer growing season essential to favor limited winter injuries and support a quick recovery in the spring. March seeding can also be more effective than April seeding. Indeed, anticipating the seeding in March resulted in an earlier establishment mainly due to the quick lateral spreading of the few emerged seedlings. Favorable temperatures allow quick soil coverage regardless of the number of seeds emerged. Among cultivar tested, 'Jackpot' performed poorly in both years of investigation demonstrating weak adaptability to the local environment. Therefore, winter injuries that usually occur during the first year could be limited by a proper cultivars' selection based on the speed of establishment under nonoptimal temperatures.

Author Contributions: Conceptualization, S.M.; methodology, S.M.; software, A.O. and M.G.; validation, S.M. and A.O.; formal analysis, A.O. and C.P.; investigation, M.G.; resources, S.M.; data curation, M.G.; writing-original draft preparation, M.G.; writing-review and editing, M.G., C.P., S.M., and A.O.; visualization, C.P. and M.G.; supervision, S.M.; project administration, S.M.; funding acquisition, S.M. All authors have read and agreed to the published version of the manuscript.

Funding: This research received no external funding.

Conflicts of Interest: The authors declare no conflicts of interest. 


\section{References}

1. Giorgi, F.; Lionello, P. Climate change projections for the Mediterranean region. Glob. Planet. Chang. 2008, 63, 90-104. [CrossRef]

2. Minelli, A.; De Luca, A.; Croce, P.; Cevenini, L.; Zuffa, D. Transition from cool-season to warm-season grass: Environmental effects in a golf course in the North of Italy. In Proceedings of the Fourth European Turfgrass Society Conference, Osnabrueck, Germany, 6-9 July 2014; pp. 1-4.

3. Croce, P.; De Luca, A.; Mocioni, M.; Volterrani, M.; Beard, J.B. Warm-season turfgrass species and cultivar characterizations for a Mediterranean climate. Int. Turfgrass Soc. Res. J. 2001, 9, 855-859.

4. Macolino, S.; Serena, M.; Leinauer, B.; Ziliotto, U. Preliminary Findings on the Correlation between Water-soluble Carbohydrate Content in Stolons and First Year Green-up of Seeded Bermudagrass Cultivars. HortTech. 2010, 20, 758-763. [CrossRef]

5. Pornaro, C.; Barolo, E.; Rimi, F.; Macolino, S.; Richardson, M. Performance of various cool-season turfgrasses as influenced by simulated traffic in northeastern Italy. Eur. J. Hort. Sci. 2016, 81, 273-276. [CrossRef]

6. Rimi, F.; Macolino, S.; Richardson, M.D.; Karcher, D.E.; Leinauer, B. Influence of Three Nitrogen Fertilization Schedules on Bermudagrass and Seashore Paspalum: II. Carbohydrates and Crude Protein in Stolons. Crop Sci. 2013, 53, 1168-1178. [CrossRef]

7. DiPaola, J.M.; Beard, J.B. Physiological Effects of Temperature Stress. Turfgrass 1992, 32, 231-267.

8. Schiavon, M.; Macolino, S.; Leinauer, B.; Ziliotto, U. Seasonal Changes in Carbohydrate and Protein Content of Seeded Bermudagrasses and Their Effect on Spring Green-Up. J. Agron. Crop Sci. 2016, 202, 151-160. [CrossRef]

9. Hatfield, J. Turfgrass and Climate Change. Agron. J. 2017, 109, 1708-1718. [CrossRef]

10. Magni, S.; Gaetani, M.E.; Grossi, N.; Caturegli, L.; Bella, S.L.; Leto, C.; Virga, G.; Tuttolomondo, T.; Lulli, F.; Volterrani, M. Bermudagrass adaptation in the Mediterranean climate: Phenotypic traits of 44 accessions. Adv. Hort. Sci. 2014, 28, 29-34.

11. Pornaro, C.; Macolino, S.; Richardson, M.D. Rhizome and stolon development of bermudagrass cultivars in a transition-zone environment. Acta Agric. Scand. BSP 2019, 69, 657-666. [CrossRef]

12. Shaver, J.B.; Richardson, M.D.; McCalla, J.H.; Karcher, D.E.; Berger, P.J. Dormant Seeding Bermudagrass Cultivars in a Transition-Zone Environment. Crop Sci. 2006, 46, 1787-1792. [CrossRef]

13. Anderson, J.A.; Taliaferro, C.M. Freeze Tolerance of Seed-Producing Turf Bermudagrasses. Crop Sci. 2002, 42, 190-192. [CrossRef] [PubMed]

14. Patton, A.J.; Richardson, M.D.; Karcher, D.E.; Boyd, J.W.; Reicher, Z.J.; Fry, J.D.; McElroy, J.S.; Munshaw, G.C. A Guide to Establishing Seeded Bermudagrass in the Transition Zone. Appl. Turfgrass Sci. 2008, 5, 19. [CrossRef]

15. Patton, A.J.; Hardebeck, G.A.; Williams, D.W.; Reicher, Z.J. Establishment of Bermudagrass and Zoysiagrass by Seed. Crop Sci. 2004, 44, 2160-2167. [CrossRef]

16. Severmutlu, S.; Mutlu, N.E.D.İ.M.; Shearman, R.C.; Gurbuz, E.; Gulsen, O.; Hocagil, M.; Karaguzel, O.; Heng-Moss, T.; Riordan, T.P.; Gaussoin, R.E. Establishment and Turf Qualities of Warm-season Turfgrasses in the Mediterranean Region. HortTechnology 2011, 21, 67-81. [CrossRef]

17. Philley, H.W.; Krans, J.V.; Goatley, J.M.; Maddox, V.L. Turf Performance of Seeded Bermudagrass Cultivars in Mississippi. Bull. Missisipi State University 2009, 1088, 1-9.

18. Pornaro, C.; Macolino, S.; Leinauer, B. Seeding time affects establishment of warm-season turfgrasses. Acta Hortic. 2016, 1122, 27-34. [CrossRef]

19. Richardson, M.D.; Karcher, D.E.; Berger, P.; Boyd, J.W. Utilizing improved seeded bermudagrasses on transition-zone sports fields. Acta Hortic. 2003, 661, 369-374. [CrossRef]

20. Regional Agency for Environmental Protection of Veneto Region (ARPAV). Dipartimento Per La Sicurezza Del Territorio. Centro Meterologico: Teolo, Padova, Italy. Available online: http://www.arpa.veneto.it/datiambientali/open-data/clima/principali-variabili-meteorologiche (accessed on 15 July 2020).

21. Soil Survey Staff. Soil Survey Staff. Soil Taxonomy: A basic System of Soil Classification for Making and Interpreting Soil Surveys. In U.S. Department of Agriculture Handbook, 2nd ed.; Natural Resources Conservation Service: Washington, DC, USA, 1999; p. 436.

22. Richardson, M.D.; Karcher, D.E.; Purcell, L.C. Quantifying Turfgrass Cover Using Digital Image Analysis. Crop Sci. 2001, 41, 1884. [CrossRef] 
23. Busey, P.; Myers, B.J. Growth Rates of Turfgrasses Propagated Vegetatively 1. Agron. J. 1979, 71, 817-821. [CrossRef]

24. Leinauer, B.; Serena, M.; Singh, D. Seed Coating and Seeding Rate Effects on Turfgrass Germination and Establishment. Horttechnology 2010, 20, 179-185. [CrossRef]

25. Leinauer, B.; Serena, M.; Shiavon, M. Comparing spring and summer establishment of bermudagrass seed and sod under two irrigation systems using saline water. TurfNews (May/June) 2009, 33-36.

26. Giolo, M.; Ferrari, F.; Macolino, S. Estimation of Base Germination Temperature of Ten Seeded-Type Bermudagrass Cultivars. Eur. J. Hortic. Sci. 2014, 79, 129-134.

27. Giolo, M.; Pornaro, C.; Sellenave, R.; Macolino, S.; Leinauer, B. Base Temperatures Affect Accuracy of Degree Day Model to Predict Seedling Emergence of Bermudagrasses. Agron. J. in press.

28. R Core Team. R: A Language and Environment for Statistical Computing; R Foundation for Statistical Computing: Vienna, Austria, 2013.

29. Lenth, R.; Singmann, H.; Love, J.; Buerkner, P.; Herve, M. emmeans: Estimated Marginal Means, aka Least-Squares Means. Available online: https:/github.com/rvlenth/emmeans (accessed on 11 June 2020).

30. Bretz, F.; Torsten, H.; Westfall, P. Multiple Comparisons Using R, 1st ed.; CRC Press, Taylor \& Francis Publishing Company: Boca Raton, FL, USA, 2011.

31. Addinsoft. XLSTAT Statistical and Data Analysis Solution; Addinsoft: Boston, MA, USA, 2020.

32. Giolo, M.; Benincasa, P.; Anastasi, G.; Macolino, S.; Onofri, A. Effects of Sub-Optimal Temperatures on Seed Germination of Three Warm-Season Turfgrasses with Perspectives of Cultivation in Transition Zone. Agronomy 2019, 9, 421. [CrossRef]

33. Munshaw, G.C.; Williams, D.W.; Cornelius, P.L. Management Strategies during the Establishment Year Enhance Production and Fitness of Seeded Bermudagrass Stolons. Crop Sci. 2001, 41, 1558-1564. [CrossRef]

(C) 2020 by the authors. Licensee MDPI, Basel, Switzerland. This article is an open access article distributed under the terms and conditions of the Creative Commons Attribution (CC BY) license (http://creativecommons.org/licenses/by/4.0/). 